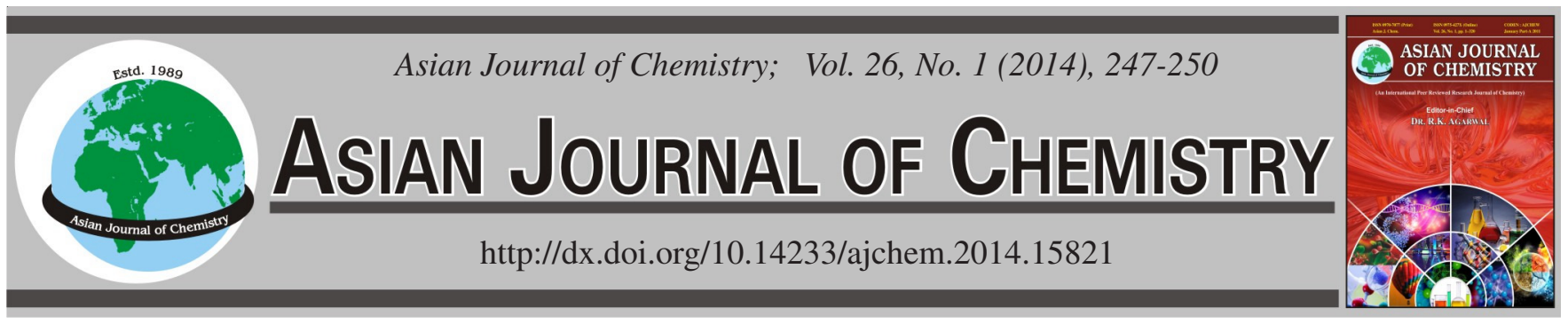

\title{
Online Upgrading of Bio-oil Pyrolyzed Form by Shrub Residues
}

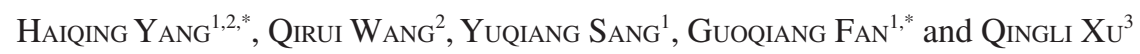

${ }^{1}$ College of Forestry, Henan Agricultural University, Zhengzhou 450002, P.R. China

${ }^{2}$ Henan Academy of Forestry, Zhengzhou 450008, P.R. China

${ }^{3}$ East China University of Science and Technology, Shanghai 450002, P.R. China

*Corresponding author: E-mail: 605870850@qq.com

Received: 23 May 2013;

Accepted: 19 September 2013;

Published online: 26 December 2013;

AJC-14515

\begin{abstract}
In this paper, the shrub residues as raw materials, were produced to upgraded bio-oil by fast pyrolysis technology and online catalytic cracking in a $5 \mathrm{~kg} / \mathrm{h}$ fluidized-bed reactor. The quality of upgraded bio-oil was significantly improved after online catalytic cracking, the oxygen content was $31.83 \%$, the water content was $22.15 \%$ and the liquid yield was $43.42 \%$ after online catalytic cracking $\left(500{ }^{\circ} \mathrm{C}\right)$. After online catalytic cracking, the content of organic acids decreased to $3.3 \%$, the content of phenols increased to $40.10 \%$ and the content of one or two benzene rings compounds increased to $16.60 \%$. This was attributed that zeolite HZSM-5 had the catalytic reforming and cyclization functions.
\end{abstract}

Keywords: Bio-oil, Pyrolysis, Shrub, Residues, Fluidized-bed, Online catalytic cracking.

\section{INTRODUCTION}

Shrubbery is an important terrestrial ecosystem, which becomes an important renewable alternative energy because of its high sprouting ability and high productivity. It is an important means to improve the yield of shrub residue through short rotation operation. Shrubbery distribution accounts for about $3 \%$ of the land area in China. According to statistics, the yield of shrub residue is up to 5-7 tons per square hectare average annual. Shrubbery is widely distributed in Taihang mountain, only Jiyuan district is more than 10,000 square hectare, which can be harvested annually 8-12 million tons of residues. The residues can be produced to fast pyrolysis oil (called bio-oil) by fast pyrolysis technology, which is not only a new way for the development and utilization of shrub residues, but can reduce the dependence on the fossil fuel.

Fast pyrolysis is regarded as a promising way to utilize biomass with high efficiency. Many researchers had investigated the production of bio-oil from various types of biomass in different reactor systems such as fixed bed reactors ${ }^{1}$, fluidized bed reactors ${ }^{2,3}$, transport and circulating fluidized bed reactors ${ }^{4,5}$, rotating cone reactors ${ }^{6}$ and ablative reactors ${ }^{7}$. However, the liquid products (called bio-oil), which contained high content of oxygen, were of low calorific value and of poor thermal stability. This disadvantage became a problem restricting its extensive application and replacement the fossil fuels. Therefore, how to use the bio-oil properly and effectively had attracted researchers' great attention in the world. At present, bio-oil upgrading technology was mainly included two methods i.e., catalytic hydrogenation ${ }^{8,9}$ and catalytic cracking ${ }^{10,11}$. Catalytic hydrogenation is a process in which bio-oil is hydrotreated under pressure (10-20 MPa) in the hydrogen ambience. Catalytic thermal cracking is, on the other hand, a process in which bio-oil is thermally treated at atmospheric pressure without hydrogen. Compared with catalytic hydrogenation, its disadvantages are low yield and easy coking, which lead to a shorter life of catalyst ${ }^{12}$ although catalytic thermal cracking proceeds at an atmospheric pressure. In addition, catalytic cracking process was carried out after the pyrolysis gas was cooled to liquid phase (bio-oil), which was not only a waste of energy, but also the deactivation of catalyst coking ${ }^{13}$. In order to save of energy, online catalytic cracking process was studied in this paper.

In this paper, shrub residues are from Taihang mountain (Jiyuan district Henan province in China) as raw materials, which was produced to bio-oil by fast pyrolysis technology and was upgraded by the method of online catalytic cracking process. The catalytic cracking temperature and properties of upgraded bio-oil were studied in this paper.

\section{EXPERIMENTAL}

Shrub residues are from Taihang mountain (Jiyuan district Henan province in China). Shrub residues were dried, crushed, sieved (pore size of sieve is 60 mesh), collected. The collected 
shrub residues were placed in an oven at $105{ }^{\circ} \mathrm{C}$ within $10 \mathrm{~h}$ before experiment. The proximate analysis and ultimate analysis were shown in Table-1. It was demonstrated that shrub residues had a high volatile matter and oxygen contents.

\begin{tabular}{lccc}
\hline \multicolumn{4}{c}{ TABLE-1 } \\
CHARACTERISTICS OF SHRUB RESIDUES \\
\hline \multicolumn{2}{c}{ Proximate analyses } & \multicolumn{2}{c}{ Ultimate analysis( wt. \% ) } \\
\hline Volatile matter (wt. \%) & 79.22 & $\mathrm{C}$ & 43.76 \\
Fixed carbon (wt. \%) & 19.13 & $\mathrm{H}$ & 6.21 \\
Ash (wt. \%) & 1.65 & $\mathrm{O}$ & 50.03 \\
H.H.V. (MJ/kg) & 18.11 & & \\
\hline
\end{tabular}

Experimental installation: The experimental installation was shown in Fig. 1. The shrub residues were sent to a fluidized bed reactor by a screw feeder when the reactor was heated externally by electricity to the desired temperature. The nitrogen gas entered from the bottom of the reactor to fluidize the sand bed. The solid product (coke) was separated from the pyrolysis products by a cyclone. The coke was sent to an ash hopper and other products were catalyzed in a fixed bed reactor. The cracking gas was cooled and then collected upgraded bio-oil from a condenser. The noncondensed gas was then scrubbed before release.

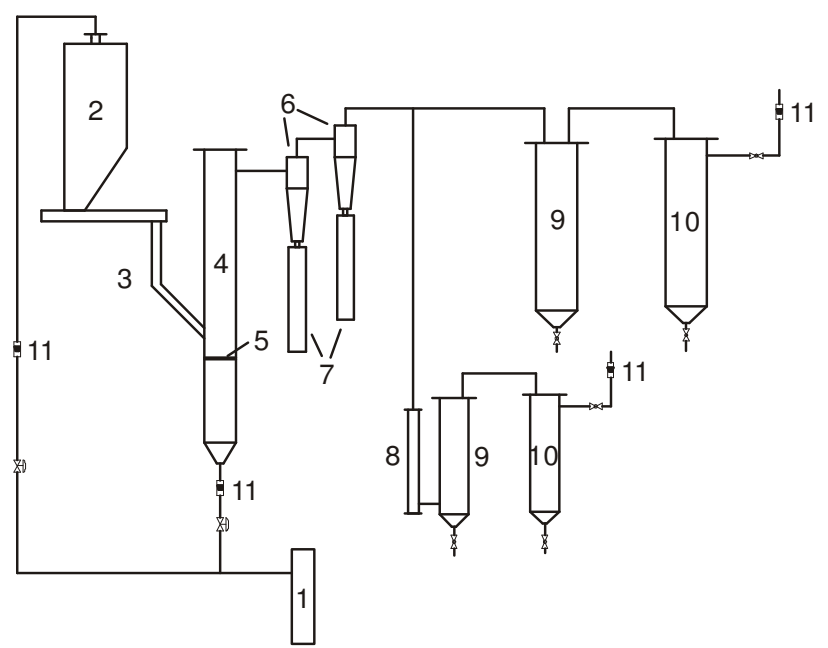

1-Nitrogen cylinder; 2- Stock hopper; 3-Feeder; 4-Fluid bed reactor; 5-Distributing plank;

6-Cyclone separator; 7-Ash hopper; 8-Fixed bed reactor ; 9- The first condenser;

10-The second condenser; 11 - Gas flowmeter

Fig. 1. Schematic diagram of experimental setup

Catalyst: The catalyst of zeolite HZSM-5 (the mole ratio of $\mathrm{Si} / \mathrm{Al}$ is 38 ) was provided by catalyst factory of Nankai University. The zeolite was calcined at $500{ }^{\circ} \mathrm{C}$ for $2 \mathrm{~h}$ and cooled to room temperature. The zeolite was crashed and sieved to the particle size of 2-3 mm, which was sent to the catalytic cracking reactor. The characteristics of zeolite were shown in Table-2.

TABLE-2

CHARACTERISTICS OF ZEOLITE HZSM-5

\begin{tabular}{ccc}
\hline $\begin{array}{c}\text { Specific surface area } \\
\left(\mathrm{m}^{2} / \mathrm{g}\right)\end{array}$ & $\begin{array}{c}\text { Averoge pore size } \\
(\mathrm{nm})\end{array}$ & Pore volume $\left(\mathrm{cm}^{3} / \mathrm{g}\right)$ \\
\hline 396.73 & 19.00 & 0.1884 \\
\hline
\end{tabular}

Product analysis: Agilent 6820 gas chromatogram equipped with unibeads $C 80 / 100$ column was used for analysis of gaseous products. Ultimate analysis was performed on a BCH-1 analyzer, which was produced by Jiangsu Jiangfen Electroanalytical Instrument Co., Ltd. The moisture content in the pyrolysis liquid products was analyzed by Karl-Fischer with toluene distillation method.

Reaction conditions: The temperature of fluidized bed reactor was $500{ }^{\circ} \mathrm{C}$, flow rate of fluidizing gas was $4 \mathrm{~m}^{3} / \mathrm{h}$, feed rate was $3 \mathrm{~kg} / \mathrm{h}$. The temperature of catalytic cracking reactor was from 390 to $500{ }^{\circ} \mathrm{C}$ and the height of catalyst was $100 \mathrm{~mm}$. When the bead was in the cracking reactor and the upgraded liquid product was called secondary thermal cracking bio-oil; when the zeolite HZSM-5 was in the cracking reactor and the upgraded liquid product was called upgraded bio-oil.

\section{RESULTS AND DISCUSSION}

The effects of online catalytic cracking on tail gas composition were shown in Table-3.

TABLE-3

COMPOSITION OF THE TAIL GAS PRODUCT

\begin{tabular}{|c|c|c|c|c|c|}
\hline & $\mathrm{H}_{2}$ & $\mathrm{CO}$ & $\mathrm{CH}_{4}$ & $\mathrm{CO}_{2}$ & $\begin{array}{l}\text { Other } \\
\text { products }\end{array}$ \\
\hline Fast pyrolysis $\left(500^{\circ} \mathrm{C}\right)$ & 8.15 & 49.32 & 11.30 & 25.44 & 5.79 \\
\hline $\begin{array}{l}\text { Secondary thermal } \\
\text { cracking }\left(500^{\circ} \mathrm{C}\right)\end{array}$ & 27.20 & 30.55 & 19.21 & 19.86 & 3.18 \\
\hline $\begin{array}{l}\text { Catalytic cracking } \\
\left(400^{\circ} \mathrm{C}\right)\end{array}$ & 7.31 & 49.78 & 11.27 & 26.54 & 5.10 \\
\hline $\begin{array}{l}\text { Catalytic cracking } \\
\left(450^{\circ} \mathrm{C}\right)\end{array}$ & 6.95 & 49.21 & 12.45 & 27.89 & 3.50 \\
\hline $\begin{array}{l}\text { Catalytic cracking } \\
\left(500^{\circ} \mathrm{C}\right)\end{array}$ & 7.13 & 49.47 & 10.30 & 29.11 & 3.99 \\
\hline
\end{tabular}

As can be seen from Table-3, the content of $\mathrm{H}_{2}, \mathrm{CO}, \mathrm{CH}_{4}$ and $\mathrm{CO}_{2}$ was 8.15 and $49.23 \%, 11.30$ and 25.44 respectively at the process of fast pyrolysis. After secondary thermal cracking, $\mathrm{H}_{2}$ content in the tail gas increased dramatically to $27.20 \%$ and $\mathrm{CH}_{4}$ content also increased to $19.21 \%$, which led to the decrease of $\mathrm{CO}$ and $\mathrm{CO}_{2}$ content. The content of $\mathrm{CO}$ and $\mathrm{CO}_{2}$ was 30.55 and $19.86 \%$ respectively. This was due to the dehydrogenation of many organic compounds and the cracking of some methyl compounds to produce methane at the process of secondary cracking $\left(500{ }^{\circ} \mathrm{C}\right)$. Compared with the process of fast pyrosysis, the content of $\mathrm{H}_{2}, \mathrm{CO}, \mathrm{CH}_{4}$ and $\mathrm{CO}_{2}$ was a little change after the online catalytic cracking. The results showed that the zeolite HZSM-5 could inhibit the dehydrogenation of organic compounds and the cracking of methyl compounds to produce methane. The zeolite HZSM-5 can promote the reaction of disproportionation, cyclization and isomerization of tail gas.

Effect of online catalytic cracking on the yield of product: Table- 4 showed the yield of gas, solid and liquid was $20.90 \%, 19.60$ and 59.50 respectively at the process of fast pyrolysis. After secondary thermal cracking, the gas yield and solid yield increased dramatically to 37.50 and $30.55 \%$ respectively and the liquid yield decreased to $31.95 \%$. This was attributed that fast pyrolysis intermediate products were cracking again in the process of secondary thermal cracking to produce gaseous product and some aromatic compounds 
was polymerized to generate more coke, which led to reduce the liquid yield. Compared with the process of fast pyrolysis and secondary thermal cracking, the process of catalytic cracking contained secondary thermal cracking and catalytic cracking. That was to say, in addition to the secondary thermal cracking reaction, the zeolite HZSM-5 was conductive to the reactions of cyclization and reforming of intermediates products, meanwhile, the zeolite HZSM-5 could inhibit the polymerization, which would increase the liquid yield and gas yield and decrease the solid yield. These conclusions were consistent with the results in Table- 4 .

\begin{tabular}{|c|c|c|c|}
\hline \multicolumn{4}{|c|}{$\begin{array}{c}\text { TABLE-4 } \\
\text { YIELD OF PRODUCT AT DIFFERENT } \\
\text { EXPERIMENT CONDITION }\end{array}$} \\
\hline & $\begin{array}{c}\text { Gas } \\
\text { yield }\end{array}$ & $\begin{array}{l}\text { Solid } \\
\text { yield }\end{array}$ & $\begin{array}{c}\text { Liquid } \\
\text { yield }\end{array}$ \\
\hline Fast pyrolysis $\left(500^{\circ} \mathrm{C}\right)$ & 20.90 & 19.60 & 59.50 \\
\hline Secondary thermal cracking $\left(500^{\circ} \mathrm{C}\right)$ & 37.50 & 30.55 & 31.95 \\
\hline Catalytic cracking $\left(400^{\circ} \mathrm{C}\right)$ & 33.25 & 24.12 & 42.63 \\
\hline Catalytic cracking $\left(450^{\circ} \mathrm{C}\right)$ & 33.60 & 23.81 & 42.59 \\
\hline Catalytic cracking $\left(500^{\circ} \mathrm{C}\right)$ & 33.43 & 23.15 & 43.42 \\
\hline
\end{tabular}

Effect of online catalytic cracking on the property of product: The properties of liquid product (bio-oil or upgraded bio-oil) were shown in Table-5.

\begin{tabular}{lccccc}
\multicolumn{7}{c}{ TABLE 5 } \\
\multicolumn{7}{c}{ PROPERTIES OF LIQUID PRODUCTS } \\
\hline & $\begin{array}{c}\text { Density } \\
(\mathrm{kg} / \mathrm{L})\end{array}$ & $\begin{array}{c}\text { Water } \\
\text { content } \\
(\%)\end{array}$ & $\begin{array}{c}{[\mathrm{C}]} \\
(\%)\end{array}$ & $\begin{array}{l}{[\mathrm{H}]} \\
(\%)\end{array}$ & $\begin{array}{l}{[\mathrm{O}]} \\
(\%)\end{array}$ \\
\hline $\begin{array}{l}\text { Fast pyrolysis } \\
\left(500^{\circ} \mathrm{C}\right)\end{array}$ & 1.22 & 33.23 & 45.50 & 6.89 & 47.61 \\
$\begin{array}{l}\text { Secondary thermal } \\
\text { cracking }\left(500^{\circ} \mathrm{C}\right)\end{array}$ & 1.20 & 30.10 & 47.12 & 6.87 & 46.01 \\
$\begin{array}{l}\text { Catalytic cracking } \\
\left(400{ }^{\circ} \mathrm{C}\right)\end{array}$ & 1.13 & 22.12 & 54.12 & 6.02 & 39.86 \\
$\begin{array}{l}\text { Catalytic cracking } \\
\left(450^{\circ} \mathrm{C}\right)\end{array}$ & 1.13 & 22.10 & 60.10 & 6.17 & 33.73 \\
$\begin{array}{l}\text { Catalytic cracking } \\
\left(500^{\circ} \mathrm{C}\right)\end{array}$ & 1.13 & 22.15 & 61.89 & 6.28 & 31.83 \\
\hline
\end{tabular}

As shown in Table-5, the water content was $33.23 \%$ in the process of fast pyrolysis, accounting for $1 / 3$ of the whole liquid product. At the same temperature, the intermediate products of fast pyrolysis were pyrolyzed again in the process of secondary thermal cracking, leading to a little decrease of the density, water content, hydrogen and oxygen content and a little increase of carbon content. However, the water content and oxygen content was dramatically decreased and carbon content was rapidly increased while the density and hydrogen content was a little change in the process of online catalytic cracking, indicating that the catalytic pyrolysis was significantly improved the quality of bio-oil. This was due to the catalytic reforming function of zeolite HZSM-5, leading to the increase of hydrophobic substances yield in the liquid products. In addition, the effect of different temperature of online catalytic cracking was studied. The results showed that the water content in the product was almost the same value (approximately $22 \%$ ) with the increase of temperature. This was attributed that the water content of upgraded bio-oil had reached saturation. The oxygen content was significantly decreased and the carbon content was rapidly increased with the temperature increasing while the hydrogen content had a little increase and the density was the same with the temperature increasing. This was due to the deoxygenation of zeolite HZSM-5 was improved with the temperature increasing, leading to the oxygen content decreased from 39.86 to $31.83 \%$. So the quality of upgraded bio-oil was significantly improved after online catalytic cracking.

Effect of online catalytic cracking on the composition of product: The fast pyrolysis oil (crude bio-oil) and online catalytic cracking oil (upgraded bio-oil, $500{ }^{\circ} \mathrm{C}$ ) were analyzed by GC/MS and the compositions were classified. The results were shown in Table-6.

\begin{tabular}{ccc}
\multicolumn{3}{c}{ TABLE-6 } \\
COMPOSITION OF THE LIQUID \\
PRODUCT (BY AREA) \\
\hline Kinds & Crude bio-oil & Upgraded bio-oil \\
\hline Acids & 13.95 & 3.30 \\
One or two benzene rings & 0.50 & 16.60 \\
Ketones & 8.02 & 4.12 \\
Phenols & 34.50 & 40.10 \\
Others compounds & 22.51 & 8.03 \\
Unidentified compounds & 20.52 & 27.85 \\
\hline
\end{tabular}

The results in Table- 6 showed that the contents of acids, ketones and phenols in crude bio-oil were higher, which relative contents were $13.95,8.02$ and $34.50 \%$ respectively. The contents of benzene and polycyclic aromatic compounds in crude bio-oil were very lower (less than $1 \%$ ). However, the content of organic acids significantly decreased from 13.95 to $3.3 \%$, the content of ketones decreased from 8.02 to $4.12 \%$ and the content of others compounds rapidly decreased from 22.51 to $8.03 \%$ after online catalytic cracking. On the contrary, the contents of phenols, unidentified compounds and one or two benzene rings compounds increased dramatically after online catalytic cracking. The above results showed that zeolite HZSM-5 had the catalytic reforming and cyclization functions.

\section{Conclusion}

Shrub residues as raw materials, were produced to upgraded bio-oil by fast pyrolysis technology and online catalytic cracking in a $5 \mathrm{~kg} / \mathrm{h}$ fluidized-bed reactor. The quality of upgraded bio-oil was significantly improved after online catalytic cracking, the oxygen content was $31.83 \%$, the water content was $22.15 \%$ and the liquid yield was $43.42 \%$ after online catalytic cracking $\left(500{ }^{\circ} \mathrm{C}\right)$.

After online catalytic cracking, the contents of organic acids and ketones in upgraded bio-oil were lower than that of crude bio-oil and the contents of phenols and one or two benzene rings compounds were higher than that of crude bio-oil. This was attributed that zeolite HZSM-5 had the catalytic reforming and cyclization functions.

\section{ACKNOWLEDGEMENTS}

The project was supported by Forestry Industry Research Special Funds for Public Welfare Projects (200904024) and the National Natural Science Foundation of China (No. 21376084). 


\section{REFERENCES}

1. M. Asadullah, M.A. Rahman, M.M. Ali, M.S. Rahman, M.A. Motin, M.B. Sultan and M.R. Alam, Fuel, 86, 2514 (2007).

2. A.A. Boateng, D.E. Daugaard, N.M. Goldberg and K.B. Hicks, Ind. Eng. Chem. Res., 46, 1891 (2007).

3. H.S. Heo, H.J. Park, Y.K. Park, C. Ryu, D.J. Suh, Y.W. Suh, J.H. Yim and S.S. Kim, Bioresour. Technol., 101, S91 (2010).

4. A. Oasmaa, Y. Solantausta, V. Arpiainen, E. Kuoppala and K. Sipila, Energy Fuels, 24, 1380 (2010).

5. T. Tzanetakis, N. Ashgriz, D. James and M.J. Thomson, Energy Fuels, 22, 2725 (2008).

6. R.H. Venderbosch and W. Prins, Bioprod. Bioresour., 4, 178 (2010).
7. J. Lédé, F. Broust, F.T. Ndiaye and M. Ferrer, Fuel, 86, 1800 (2007).

8. F. Huang, W. Li, Q. Lu and X. Zhu, Chem. Eng. Technol., 33, 2082 (2010).

9. Y. Xu, T. Wang, L. Ma, Q. Zhang and L. Wang, Biomass Bioenergy, 33, 1030 (2009).

10. S. Vitolo, M. Seggiani, P. Frediani, G. Ambrosini and L. Politi, Fuel, 78, 1147 (1999).

11. P.T. Williams and N. Nugranad, Energy, 25, 493 (2000).

12. S.T. Srinivas, A.K. Dalai and N.N. Bakhshi, Can. J. Chem. Eng., 78, 343 (2000).

13. X. Guo, Y. Yan, T. Li and Z. Ren, J. East China Univer. Sci. Technol., 29, 534 (2003). 